\title{
Identifying PV Module Mismatch Faults by a Thermography-Based Temperature Distribution Analysis
}

\author{
Yihua $\mathrm{Hu}^{1}$, Member, IEEE, Wenping $\mathrm{Cao}^{2}$, Senior Member, IEEE, Jien $\mathrm{Ma}^{3}$, Stephen Finney ${ }^{1}$, David $\mathrm{Li}^{1}$ \\ ${ }^{1}$ Department of Electronic and Electrical Engineering, University of Strathclyde, United Kingdom \\ ${ }^{2}$ School of Electronics, Electrical Engineering and Computer Science, Queen's University Belfast, United Kingdom \\ ${ }^{3}$ College of Electrical Engineering, Zhejiang University, China
}

\begin{abstract}
Photovoltaic solar power generation is proven to be effective and sustainable but is currently hampered by relatively high costs and low conversion efficiency. This paper addresses both issues by presenting a low-cost and efficient temperature distribution analysis for identifying PV module mismatch faults by thermography. Mismatch faults reduce the power output and cause potential damage to $\mathrm{PV}$ cells. This paper firstly defines three fault categories in terms of fault levels, which lead to different terminal characteristics of the PV modules. The investigation of three faults is also conducted analytically and experimentally and maintenance suggestions are also provided for different fault types. The proposed methodology is developed to combine the electrical and thermal characteristics of PV cells subjected to different fault mechanisms through simulation and experimental tests. Furthermore, the fault diagnosis method can be incorporated into the maximum power point tracking (MPPT) schemes to shift the operating point of the PV string. The developed technology has improved over the existing ones in locating the faulty cell by a thermal camera, providing a remedial measure and maximizing the power output under faulty conditions.
\end{abstract}

Index Terms -Degradation, fault diagnosis, photovoltaic power systems, temperature, thermography.

\section{INTRODUCTION}

Fossil fuel-based electricity generation emits greenhouse gases, causes global warming, and is environmentally unsustainable. Renewable energy (e.g. solar, wind, geothermal, tidal and wave), on the other hand, has received much attention and enormous research and development funding across the world over the years. Currently, grid-connected photovoltaic $(\mathrm{PV})$ power is gaining in popularity in the global renewables market, primarily owing to mass production of $\mathrm{PV}$ panels to reduce the capital costs and continuous improvement in power conversion technologies. However, current bottlenecks are still associated with high costs and low efficiency of PV systems.

Copyright $\odot 2014$ IEEE. Personal use of this material is permitted. However, permission to use this material for any other purposes must be obtained by sending a request to pubs-permissions@ieee.org
In addition to capital costs, the maintenance costs for PV panels are also high because they are generally installed in outdoor environments and they are prone to various mechanical and electrical faults. These faults can result in additional power losses [1], hotspots [2], different irradiances between PV modules [3]. These lead to loss of production and reduced generation efficiency. If left untreated, the faults may propagate to neighbouring modules and cause a complete failure of the PV strings. The reliability, availability and maintainability (RAM) [4] of PVs have been a heated topic in research and application community [5] over the last three decades. In the literature, numerous diagnostic and monitoring methodologies have been proposed to minimize the outage period and to maximize the lifetime output of the PV systems [6]-[29].

\section{Fault Mechanisms AND Detection Methods}

In general, there are three levels of faults developed in the PV systems: cell-, module- and string-levels [6]. The cell faults include mechanical cracks, corrosion by water permeation, and material degradation by ultraviolet or thermal stress. The module faults are related to open-circuits or short-circuits resulting from the degeneration of the cells, cover or sealant materials. The PV string faults consist of open-circuits, short-circuits, mismatch between PV modules, and partial shading. Mismatch faults are generally caused by encapsulant degradation, anti-reflection coating deterioration, manufacturing defects and partial shading [30].

In a PV system, PV cells are connected in series to form a PV module, as shown in Fig. 1. A number of PV modules are then connected in series to form a PV string. Strings are further connected in parallel to form a PV array. This arrangement enables low DC voltage and current to be added up to a high output. For any solar power plants, the PV panels need to take up a large space, which is likely to cause some non-uniform illumination when shadows or leaves cover part of the PV modules. This effect is termed partial shading [7]-[12]. 


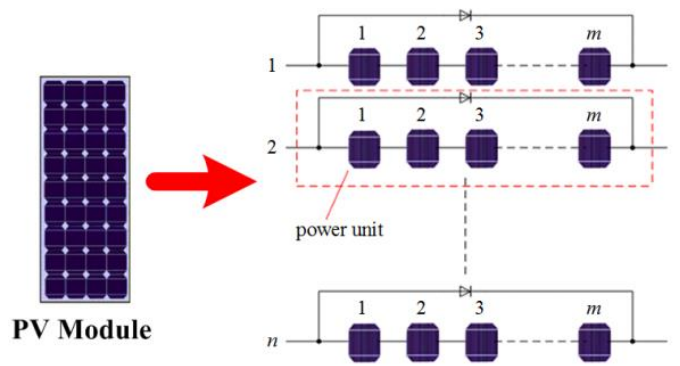

Fig. 1 Power units in a PV module.

If a PV array is under non-uniform illumination, the transferred electricity drops dramatically [7][8], thus reducing the output power and generation efficiency. Under partial shading conditions, mismatch faults cause overheating of some "faulted" cells/modules as well as multiple local maximum power points (MPPs). By developing analytical models of PVs, paper [13] simulates the electrical output characteristics of shadow-influenced PV arrays. The PV's current-voltage and power-voltage curves are characterized by multiple steps and peaks [13]. In practice, bypass diodes are generally added between the PV strings at the terminal to reduce the voltage imbalance [14]. Nonetheless, this causes a difficulty to track the MPP [15]. As a consequence, when mismatch faults occur, conventional maximum power point tracking (MPPT) techniques become unsuitable to track the global maximum power point [16][17]. Other tracking techniques such as particle swarm optimization [8], fuzzy logic [18] and power regulation [19] are devised to aid in this process. It is therefore important to develop a fault diagnostic system to detect any PV mismatch and to optimize the MPPT control accordingly. In the literature, common fault detection techniques include electrical (e.g. terminal measurements), visual (e.g. observing tarnish of cells and modules) and thermal approaches (e.g. spot heating). This paper attempts to improve energy efficiency and cost efficiency of PV systems by identifying mismatch faults and providing a remedial MPPT technique to suppress the mismatch, based on a temperature distribution analysis using a thermal camera.

Currently, thermal cameras are a useful tool for PV array fault diagnosis [20]-[29]. The health state of a grid-connected 20-kWp PV plant was investigated using a thermal camera [20]. It is effective to identify breakdowns and hot-spots but fails to distinguish the different types of cell faults. Kaplani [21] studied the degradation of a PV system in the bus bars, contact solder bonds, blisters, hot spots, and also developed an algorithm to automatically differentiate faulty and healthy cells. Buerhopa et al. [22] reported the temperature differences for different faults such as bypassed substring, cell fracture, soldering, and shunted cell faults. Krenzinger and Andrade [24] investigated the thermal issues of the PV panel glass by developing an accurate temperature measurement method to offset reflection errors. Simon and Meyer [25] used infrared thermography to map the surface temperature distribution of a PV panel in a reverse bias mode in order to find the causes of localized heating. Kurnik et al. [26] derived an empirical coefficient for estimating the PV module temperature determined by analytical and experimental methods. However, in these papers, thermal cameras were only used independently to detect the temperature difference between cells or modules while captured image results are still open to human interpretation on whether or not the modules are faulty and how severe a fault may be.

In this study, thermal images are processed and input to a mathematical model for extracting quantitative information of a mismatch fault, which is then employed to regulate the MPPT control. This model combines electrical and thermal models through an energy balance based on a temperature distribution analysis. After the temperature distribution characteristics are attained, the measured temperature difference can be evaluated and a new MPPT scheme can be incorporated to minimize the impact of the occurred mismatch faults.

\section{MODELING}

When developing a parameter-based PV model, the electrical and thermal characteristics of the PV module should be included as they play an important role in the overall performance of PV systems. Fortunately, the electrical and thermal characteristics are interlinked through an energy balance that all receiving solar energy must be converted into electrical or heat energy.

\section{A. Electrical Model}

The electrical characteristic of a PV cell is influenced by both illumination and environmental temperature. The electrical model of a PV cell is generally represented by an equivalent circuit [see Fig. 2(a)] and is expressed by the following equations [10][27]-[34].

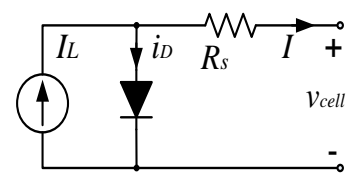

(a) Equivalent Circuit [1]

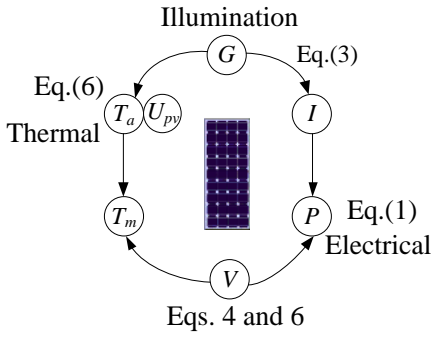

(b) Energy balance
Fig. 2 Electrical and thermal characteristics of a PV cell.

where

$$
\begin{gathered}
I=I_{\mathrm{L}}-I_{\mathrm{o}}\left[\exp \left(\frac{\varepsilon \cdot V}{T_{m}}\right)-1\right] \\
\varepsilon=\frac{q}{N_{s} \cdot K \cdot A}
\end{gathered}
$$

$$
\begin{gathered}
I_{L}=\frac{G}{G_{r e f}}\left[I_{L r e f}+k_{i}\left(T_{m}-T_{r e f}\right)\right] \\
I_{o}=I_{\text {oref }}\left(\frac{T_{m}}{T_{r e f}}\right)^{3} \exp \left[\frac{q \cdot E_{B G}}{N_{s} \cdot A \cdot K}\left(\frac{1}{T_{r e f}}-\frac{1}{T_{m}}\right)\right]
\end{gathered}
$$

where $I$ is the PV module output current, $I_{L}$ the output current, $q$ the quantity of electric charge, $A$ the diode characteristic factor, $K$ the Boltzmann constant, $I_{o}$ the saturated current, $T_{m}$ the PV module temperature, $G$ the real irradiance of the PV cell, $V$ the output voltage, $G_{r e f}$ the reference irradiance level $\left(1000 \mathrm{~W} / \mathrm{m}^{2}\right)$, 
$I_{\text {Lref }}, I_{\text {oref }}$ the reference values for $I_{L}$ and $I_{o}, k_{i}$ the current-temperature coefficient, normally provided by the manufacturer. $T_{r e f}$ is the reference temperature, $N_{s}$ is the number of series-connected cells, $T_{m}$ is the PV module temperature. $\varepsilon$ is a constant depending on $q, N_{s}, K, A$, and is calculated by the following equation:

$$
I_{s c_{-} r e f}-I_{m p p_{-} r e f}=\frac{I_{s c_{-} r e f}}{\exp \left(\frac{\varepsilon \cdot V_{o c_{-} r e f}}{T_{r e f}}\right)-1}\left[\exp \left(\frac{\varepsilon \cdot V_{m p p_{-} r e f}}{T_{r e f}}\right)-1\right]
$$

where $I_{m p p \_r e f}, I_{s c_{-} r e f}$ and $V_{\text {oc_ref }}$ are the MPP current, short-circuit current and open-circuit voltage at a reference condition defined by the relevant standard.

\section{B. Energy Balance}

Energy balance can link electrical with thermal circuits based on two assumptions [35]: (i) the temperature difference between the PV cell and cover glass is neglected; (ii) the cell temperature is uniform in a healthy module.

Therefore, the steady-state energy balance in PVs is given by

$$
G \cdot A_{m}=V \cdot I+U_{p v} \cdot A_{m}\left(T_{m}-T_{a}\right)
$$

where $T_{a}$ is the ambient temperature, $U_{p v}$ is an overall heat exchange coefficient from the module to ambient, and $A_{m}$ is the PV panel area.

Eqs. (1) and (6) describe the electrical and thermal models, respectively, using main parameters such as $I, V, T_{m}, G, U_{p v}$, and $T_{a}$. Fig. 2(b) further illustrates the multi-physics loop of the energy balance in the PV system. The electrical parameters are mainly influenced by the effective solar energy $S$ and module temperature $T_{m}$ while the thermal parameters by the electrical power $E$ and effective solar illumination $G$. Given a value of $S$, $T_{m}$ depends on the electrical power of the PV module. As a result, this parameter-based model can be used to investigate the temperature difference upon a PV module fault.

\section{TEMPERATURE DISTRIBUTION ANALYSIS}

When a mismatch fault occur in the PV array, a temperature difference between the healthy and an unhealthy module is created, similar to partial shading observed from the terminal. Consequently, excessive heat and thermal stress can result in cell cracks. If the cell temperature exceeds its critical temperature, the delamination of cell encapsulants may occur. If the reverse bias exceeds the cell's breakdown voltage, the cell will be damaged [30]. In terms of the severity of mismatch faults, this paper defines three categories: minor-, medium- and heavy-faults. Their terminal characteristics are different in the following aspects:

(i) Under a minor fault, the faulted power unit in the PV panel can still operate to generate electricity. As illustrated by the single arrow in Fig. 3(a), the current still passes through the PV cells string to generate an output. In this case, the faulty cell becomes an electrical load, powered by the healthy ones.

(ii) Under a medium fault, PV cells in the string are characterized by varying illumination levels. As presented in Fig. 3(b), the faulted cells can still operate as a source with a reduced power output. Because of the non-uniform illumination, the actual working point of the power unit is dictated by the operating point of the PV array. (iii) Under a heavy fault condition, the whole PV string is out of function whilst the bypass diode conducts to transmit the current, as indicated by the dotted arrow in Fig. 3(a). In essence, all PV cells in the string are open circuited.

If there exists a meaningful temperature difference, hot-spot suppression is needed to shift the system MPP and to minimize the impact of the mismatch fault [36].

\section{A. Analysis of Minor Faults}

A temperature profile of the PV array under minor fault conditions is presented in Fig. 4(a). The array is composed of $b$ rows and $a$ columns of PV modules where Module 21 is faulted. $I_{\text {array }}$ and $V_{\text {array }}$ are the current and voltage of the PV array, respectively. $I_{H}$ and $I_{f}$ are the currents of healthy and faulty strings, respectively. $V_{H}$ is the module voltage of a healthy string, $V_{H}$, the voltage of the healthy module in the faulty string, $T_{H}$ the module temperature of a healthy string, $T_{H}$, the healthy module temperature within a faulted string, and $T_{f}$ is the healthy cell temperature in a faulty power unit.

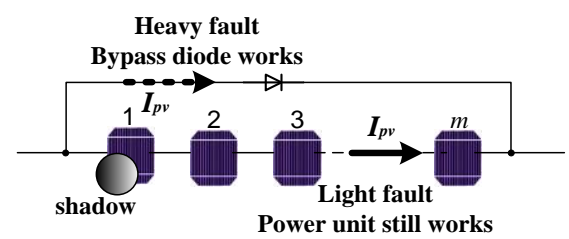

(a) Minor and heavy fault conditions

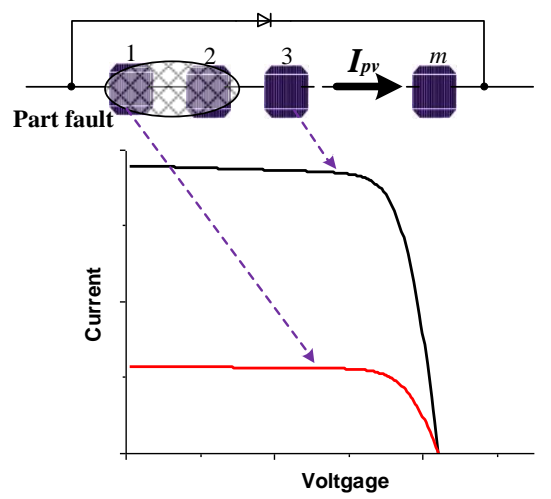

(b) Medium fault condition

Fig. 3 Three categories of mismatch faults defined for a PV system.

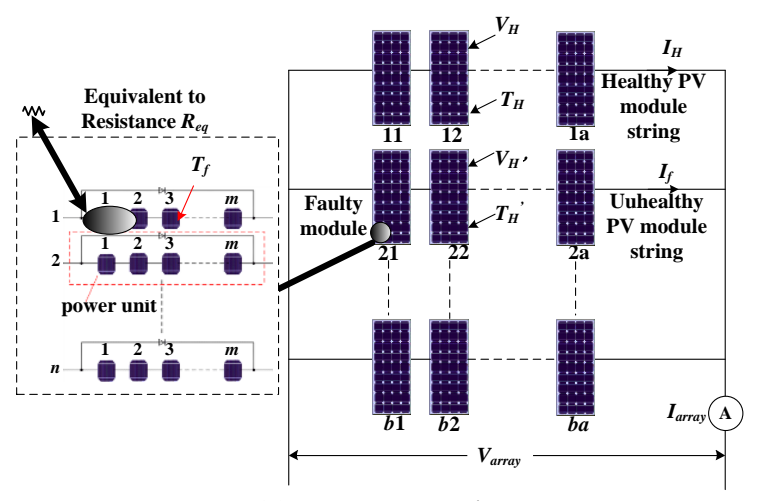

(a) PV array matrix 


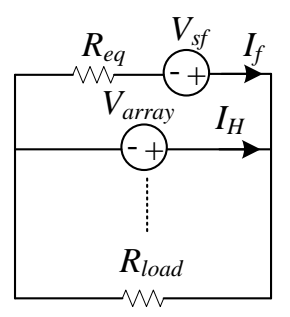

(b) Equivalent circuit upon a fault

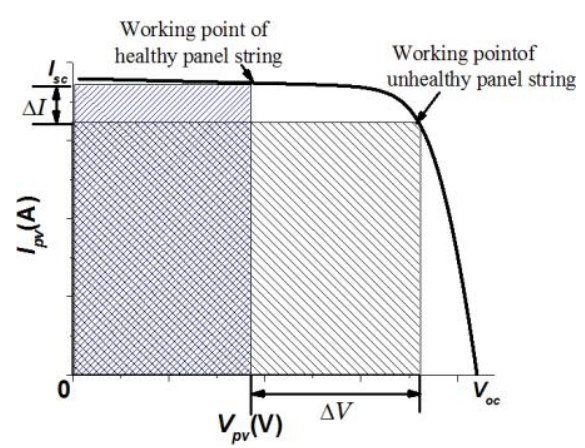

(c) Shift of working points

Fig. 4 The PV system at a minor fault condition.

Under a minor fault condition, the faulty PV cell cannot generate electricity and becomes a resistive load $\left(R_{e q}\right)$. Owing to the series connection structure, the healthy cells supply power to the faulty PV cells (released as heat), and then creates some hot-spots. An equivalent circuit of the PV array is presented in Fig. 4(b), where $V_{s f}$ stands for the voltage generated by the healthy PV cells in a faulty PV string and $R_{\text {load }}$ is the load resistance.

The electric characteristics of a faulty PV string are:

$$
\begin{gathered}
V_{s f}-I_{f} R_{e q}=V_{\text {array }} \\
I_{f}=\frac{V_{s f}}{R_{e q}+R_{\text {load }}} \\
R_{e q}=\frac{V_{s f}-V_{\text {array }}}{I_{f}} \\
\Delta V=V_{H^{\prime}}-V_{H} \\
\Delta I=I_{H}-I_{f} \\
I_{f}^{2} \cdot R_{e q}<I_{f}\left(m-m_{x}\right) \frac{V_{H^{\prime}}}{m \cdot n}
\end{gathered}
$$

where $\Delta I$ is the current difference between the healthy and unhealthy strings, $\Delta V$ is the voltage difference between the healthy modules in healthy and unhealthy strings, and $m_{x}$ is the number of faulty PV cells.

From Fig. 4(b), the voltage of a PV cell in a healthy string is lower than that of a healthy cell in a faulty string; the current of a PV cell in a healthy string is higher than that of a healthy cell in a faulty string. Eqs. 10-12 express the mathematical relationship for faulty and healthy PV strings. Eq. 12 shows that when the output power of a faulted PV unit is higher than the $I^{2} R$ power of its equivalent resistance, a minor fault is created and hot-spots begins to form on the fault cell.

Since the electrical power generated by healthy cells in the PV string supplies not only the load but also faulted cells (heating), the operating point in the current-voltage curve is effectively shifted. Fig. 4(c) demonstrates this in a PV system including healthy and unhealthy panel strings.

\section{B. Analysis of Heavy Faults}

Under a heavy fault condition, the PV string containing the faulted cell/module loses production. Its operating points are illustrated in the output current-voltage curve in Fig. 5. Point A1 is the working point of the modules in the healthy string, A2 the working point of the healthy modules in the faulty string, and A3 the working point of healthy cells in the faulty module.

Because the faulty power unit is short-circuited by the bypass diode, the healthy cells in the faulty string are effectively open-circuited. The relative positions of A1, A2, and A3 are determined by the PV array structure and its electrical characteristics. Due to the anti-parallel connection of the bypass diode, the faulty PV power unit is shorted by the diode. Therefore, its output voltage becomes zero. From Eq. 14, $V_{H}$ is less than $V_{H} ; I_{H}$ is greater than $I_{f}$, corresponding to the working points A1 and A2. $T_{H}$ and $T_{H}$, depend on the working points A1 and $\mathrm{A} 2$ in the curve. Because the faulty power unit is shorted by a bypass diode, the PV cells are open-circuited, corresponding to point A3. The output power of the faulted power unit is lower than the needed power of the equivalent resistance upon a fault; the power unit is shorted by the bypass diode.

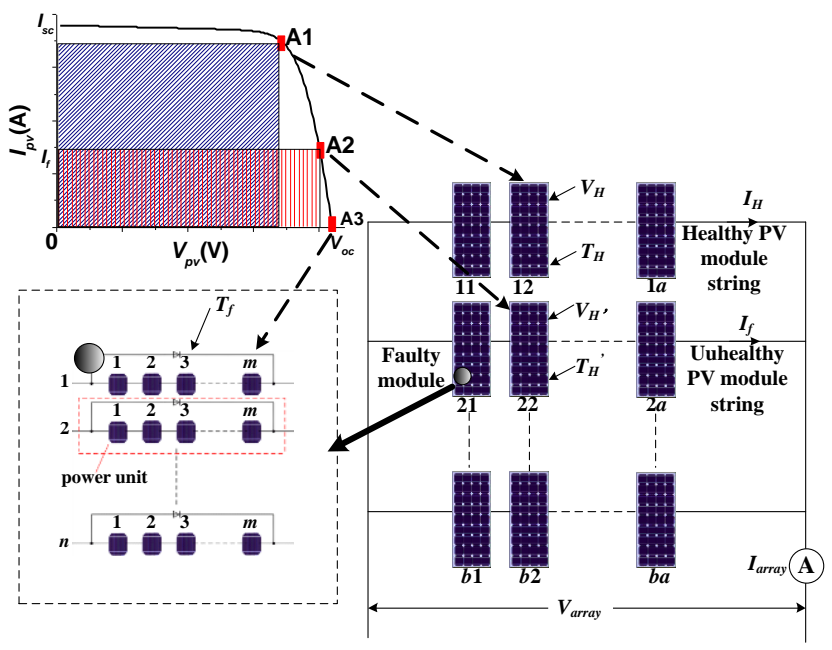

Fig. 5 The PV system at a heavy fault condition.

$V_{H}$ and $V_{H}$ are thus given by

$$
\begin{gathered}
V_{H}=\frac{V_{a r r a y}}{a} \\
V_{H^{\prime}}=\frac{V_{H} \cdot a \cdot n}{a \cdot n-n_{x}}
\end{gathered}
$$

where $n_{x}$ is the number of faulty power units in the faulty PV panel string, which can be identified by thermal cameras.

\section{Analysis of Medium Faults}

The operating point of the PV array strongly affects the condition of the healthy PV modules in the healthy string and sometimes in the fault string. Fig. 6(a) shows a $2 \times 3 \mathrm{PV}$ array under a medium fault, where module 21 is a faulted PV module and the rest of PV modules are healthy. Compared with other PV module $\left(1000 \mathrm{~W} / \mathrm{m}^{2}\right)$, No. 21 has the lower illumination 
$\left(300 \mathrm{~W} / \mathrm{m}^{2}\right)$. Fig. $6(\mathrm{~b})$ and (c) present the current-voltage and power-voltage curves, respectively, obtained from simulation.

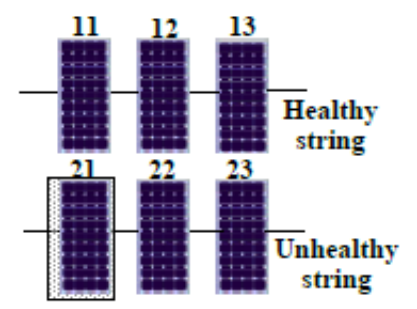

(a) Faulted module in a PV array

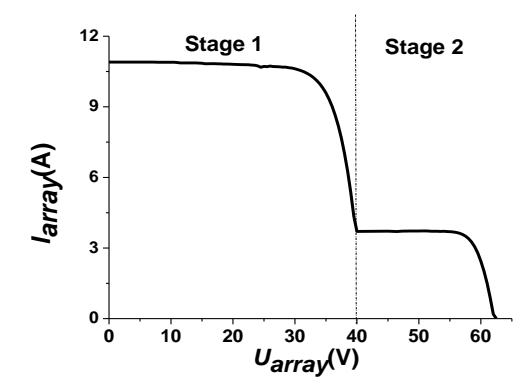

(b) Voltage-current curve of the faulted PV string

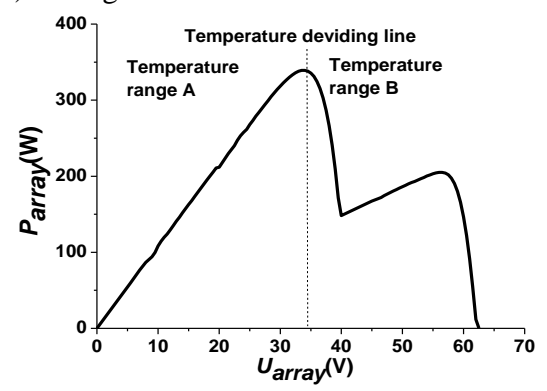

(c) Power-voltage curve of the faulted PV string

Fig. 6 The PV system at a medium fault condition.

In Fig. 6(b), the current-voltage curve of the PV array has a multi-stage feature and the power-voltage curve has thus multiple maximum power points. Two stages are identified in this figure. In Fig. 6(c), there exists a temperature dividing line in the power-voltage curve, separating two temperature ranges.

When the PV array works at stage 1, the current is between 4.5-10.8 A and the corresponding voltage is $0-40 \mathrm{~V}$. Both healthy and unhealthy string can generate electricity. Since there are two healthy modules in the faulted string, they collectively provide an output voltage of $0-40 \mathrm{~V}$. In the temperature range $A$, the temperature of modules 22 and 23 is lower than that of modules 11-13. According to the electrical and thermal balance equations, the output electrical power of the healthy modules in the faulty sting is higher than that of the healthy string. The corresponding temperature of the PV modules in the faulted string is lower than that in the healthy string.

While the PV array works at stage 2, the current is $0-4.5 \mathrm{~A}$ and the corresponding voltage is 40-62 V. In the case, only healthy string can generate electricity. The faulty string is shorted by the bypass diode and the healthy module in the faulted string is in open circuit. In effect, all the effective solar energy is transferred into heat. In temperature range $B$, the faulted string has a higher temperature than the healthy string, indicating a different temperature characteristic to range $A$.

\section{Terminal Characteristics of the Three Mismatch Faults}

Based on a thermal image, PV array current and voltage information, three mismatch faults can be clearly identified.

A minor fault will cause hot spots characterized by a small faulty cell area (e.g. bird drops or leaves). When this fault occurs, it is easy to clear but often needs human intervention.

A medium fault and a heavy fault are both caused by non-uniform illumination. For the medium fault, the faulty PV string can still generate a high voltage output (140-180 V in Fig. 7). In the high voltage region, the output current in the faulty string is significantly lower than normal strings. While for the heavy fault, the faulty PV string is shorted so that it can not generate any output. Therefore, the high-voltage region $(140-180 \mathrm{~V})$ is absent from the output curve in Fig. 7. Clearly, the medium and heavy faults can be easily distinguished. The medium and heavy faults would not cause an immediate damage to the PV module but can cause non-uniform aging and long-term damage to PV modules if left untreated.

\section{EXPERIMENTAL TESTS}

A PV experimental platform is developed using six PV panels arranged into two strings, with each having three series-connected PV panels, which are made of polysilicon and whose specifications are given in Table I. The PV panels' surface temperature is recorded by a Fluke thermal camera whose specifications are also listed in Table I.

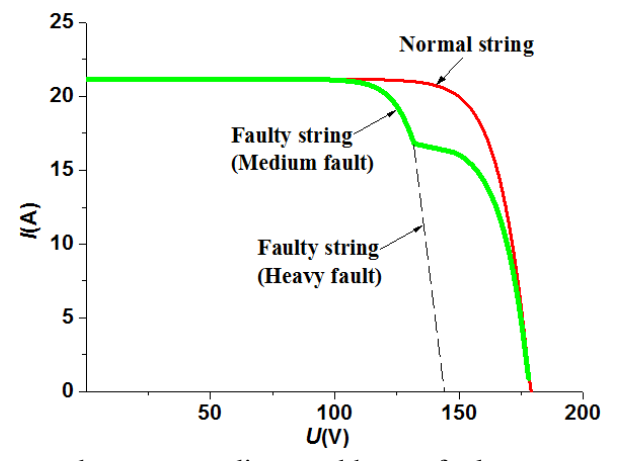

Fig. 7 Difference between medium and heavy faults.

TABLE I

SPECIFICATIONS OF THE EQUIPMENT

\begin{tabular}{cll}
\hline & \multicolumn{1}{c}{ Parameter } & \multicolumn{1}{c}{ Value } \\
\hline Item & Open-circuit voltage & $21.8 \mathrm{~V}$ \\
& Short-circuit current & $6.23 \mathrm{~A}$ \\
& Power output & $100 \mathrm{~W}$ \\
PV & MPP current & $5.69 \mathrm{~A}$ \\
Module & MPP voltage & $17 \mathrm{~V}$ \\
& Current temperature coefficient & $0.06 \% / \mathrm{K}$ \\
& Voltage temperature coefficient & $-0.36 \% / \mathrm{K}$ \\
& Power temperature coefficient & $-0.45 \% / \mathrm{K}$ \\
& NOCT & $46 \pm 2$ \\
\hline \multirow{4}{*}{ Thermal } & Type & FLUKE Ti10 \\
& IR resolution & $160 \times 120$ pixels \\
& Thermal sensitivity (NETD) & $<0.13^{\circ} \mathrm{C} / 130 \mathrm{mK}$ \\
& Minimum focus distance & $15 \mathrm{~cm}$ \\
& Spatial resolution (IFOV) & $2.5 \mathrm{mRad}$ \\
& Image frequency & $9 \mathrm{~Hz}$ \\
& Accuracy & $\pm 2^{\circ} \mathrm{C} \mathrm{or} 2 \%$ \\
\hline
\end{tabular}

The thermal camera can record a color image in varying intensities and send it to a central computer. In order to analyze 
the thermal feature of the device under test, the thermography of each PV panel is extracted by freehand cropping in a MatLab program and is then used to calculate its relative temperature with a reference. Although the absolute accuracy of the thermal camera is only $\pm 2^{\circ} \mathrm{C}$, its sensitivity is better than $0.1^{\circ} \mathrm{C}$. In this work, the proposed fault category analysis is based on identifying the temperature difference in the thermal image of the PV module and is thus effective.

Without a doubt, the use of thermal camera can help locate the faulty cells instantly and guide the maintenance work to conduct according to the type of occurred faults.

\section{A. Tests under a Minor Fault}

Two parallel diodes are connected in the junction box, as shown in Fig. 8(a). One of the power units is connected with a resistance and the other was made open-circuited to testify the temperature characteristics under different load conditions. Thus, there are two power units in all PV modules each containing $18 \mathrm{PV}$ cells.

The corresponding thermal image is presented in Fig. 8(b). The power unit $\mathrm{A}$ temperature is $32.6^{\circ} \mathrm{C}$ and power unit $\mathrm{B}$ temperature is $36.1^{\circ} \mathrm{C}$. Because some of the solar energy in unit $A$ is converted into electricity, its surface temperature is lower than that of unit $B$, in which all of the solar energy is transferred into heat.

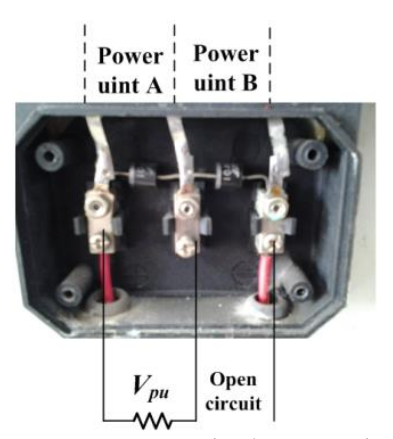

(a) Terminal connection.

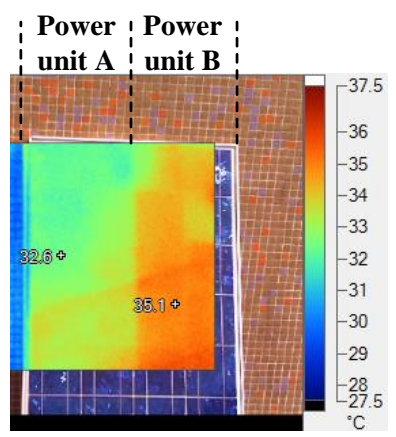

(b) Thermal image
Fig. 8 Photos of the PV module.

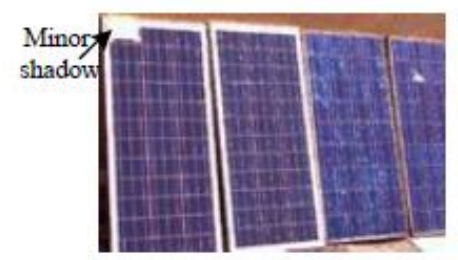

(a) Experimental scene to simulate minor shadowing

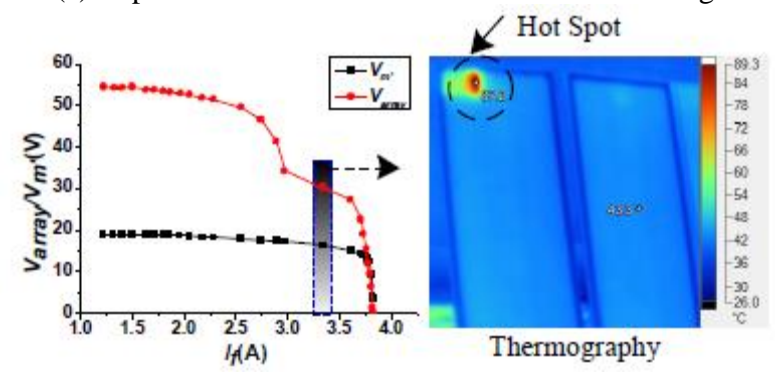

(b) Output characteristics and thermography

Fig. 9 Tests at a minor fault condition.
Three PV panels are then connected in series, and one is covered by opaque materials to emulate partial shading. As shown in Fig. 9, a hot-spot is recorded by thermography at the location of partial shading and its I-V curve is shifted as well.A further experiment is carried out under $820 \mathrm{~W} / \mathrm{m}^{2}$ illumination at $25^{\circ} \mathrm{C}$ ambient temperature. The terminal voltage is recorded $16 \mathrm{~V}$ from the faulty PV panel and $14 \mathrm{~V}$ from the two healthy panels. Because this is a minor shadow test, the healthy cells in the faulty string has a higher output voltage and the faulted cell is equivalent to a resistance, raising the output voltage of the PV string under minor fault condition. From measurements, the voltage of the faulty PV cell is $9 \mathrm{~V}$ and its equivalent resistance is $2.64 \Omega$. The electrical heating power for the faulty PV cell is $30.52 \mathrm{~W}$, and the solar energy in the hot-spot area is $15.5 \mathrm{~W}$. According to the thermography measurement, the hot-spot temperature reaches $87.2^{\circ} \mathrm{C}$, whereas the temperature of the healthy PV cells is only $44.3^{\circ} \mathrm{C}$. These are coincided with the theory analysis.

\section{B. Tests under a Heavy Fault}

Next, three PV cells are all covered up to create a heavy fault condition, as shown in Fig. 10. Compared with the minor fault scenario, the covered area is greater so that the faulted power unit is shorted by the bypass diode. The experiment is conducted under an illumination of $690 \mathrm{~W} / \mathrm{m}^{2}$ at $24^{\circ} \mathrm{C}$. The average temperature of the healthy $\mathrm{PV}$ panel is $33.7^{\circ} \mathrm{C}$, whereas the average temperature of the unhealthy PV module is $36.0^{\circ} \mathrm{C}$. The faulty PV panel is shorted by bypass diodes, and all the solar energy is converted into heat. However, the healthy PV panels are still capable of converting some of incoming solar energy into electricity, leading to a lower panel temperature. From Fig. 10, there is no current flowing at the faulted module during interval 2. Its current gradually increases during interval 1 because the faulty PV module is shorted by the bypass diode.

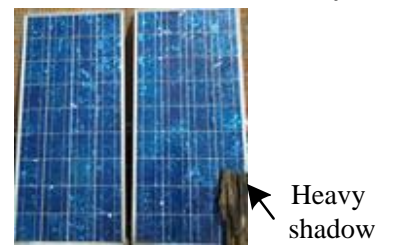

(a) Experimental scene to simulate heavy shadowing

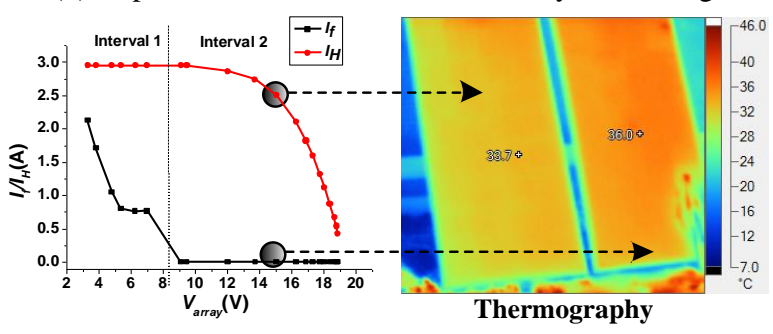

(b) Output characteristics and thermography

Fig. 10 Tests at a heavy fault condition.

\section{Tests under a Medium Fault}

In this test, one PV module is partially covered up by a thin paper to represent a medium fault condition (e.g. partial shading), as shown in Fig. 11. The reason of using a thin paper is to ensure that some illumination can penetrate into the shaded cells through the paper. In the previous cases, light penetration is almost completely stopped. 


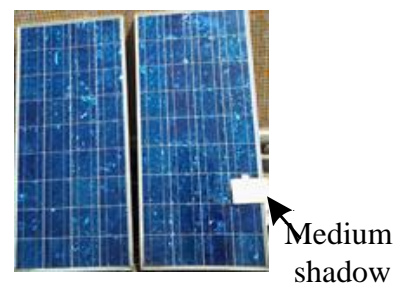

(a) Experimental scene to simulate medium shadowing

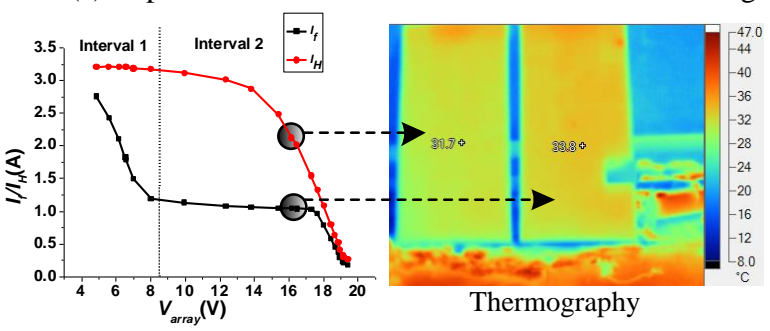

(b) Output characteristics and thermography

Fig. 11 Tests at a medium fault condition.

The experiment is carried out under an illumination of 740 $\mathrm{W} / \mathrm{m}^{2}$ at $22^{\circ} \mathrm{C}$. The faulty power unit output is influenced by the unhealthy PV cells. The average temperature of a healthy PV panel is $31.7^{\circ} \mathrm{C}$, whereas that of the unhealthy PV module is recorded $33.8^{\circ} \mathrm{C}$. In interval 1 , the faulty power unit is shorted by the bypass diode because the faulty power unit can not generate a higher enough current to support load.

\section{Tests under Different Operating Points}

Further tests are conducted to investigate the impact of the operating points, under a heavy fault condition.

Fig. 12(a) shows the photo of a $2 \times 3 \mathrm{PV}$ array employed in this experiment. Fig. 12(b) and (c) depict the output curves of the tested PV array. Fig. 12(d) shows a thermal image at working point $A$ (with an array output voltage of $34 \mathrm{~V}$ ). As discussed in Section III, the working point can cause the temperature difference. However, in this case, the two healthy modules in the fault string operate at $17 \mathrm{~V}$, which is close to the MPP voltage. The corresponding temperatures are $19.9^{\circ} \mathrm{C}$ and $19.8^{\circ} \mathrm{C}$, respectively, almost undistinguishable. The modules' output voltage in healthy string is $11.3 \mathrm{~V}$, and the corresponding temperatures are $20.9^{\circ} \mathrm{C}, 20.9^{\circ} \mathrm{C}$ and $21^{\circ} \mathrm{C}$ for the three panels. At working point $A$, the modules temperature in the healthy string is higher than the healthy module in the fault string. Fig. 12(e) shows a thermal image at the working point $B$ at the array output voltage $52 \mathrm{~V}$. The output voltage of the healthy module is $17.3 \mathrm{~V}$, which is close to MPP voltage; whereas the voltages of modules No. 22 and No. 23 are close to the open circuit voltage suggesting more energy is converted into heat. By the thermography measurement, the temperatures of healthy modules are $19.6^{\circ} \mathrm{C}, 19.7^{\circ} \mathrm{C}$ and $19.7^{\circ} \mathrm{C}$ whilst the temperatures of healthy modules in the faulty string are both $21.6^{\circ} \mathrm{C}$. The temperature difference coincides with the theoretical analysis.

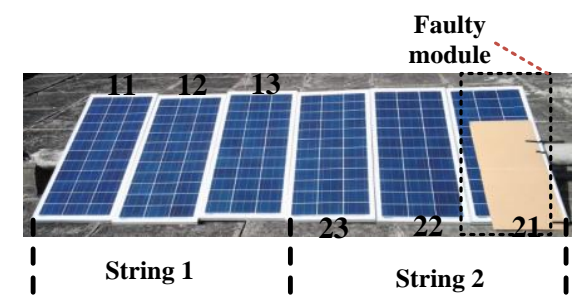

(a) Tested PV panels

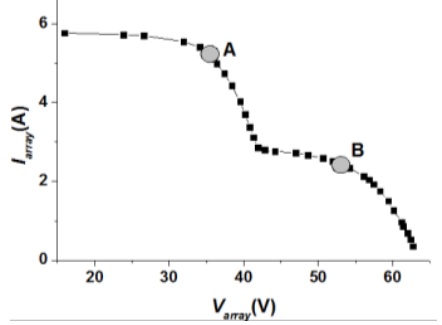

(b) Current-voltage curve

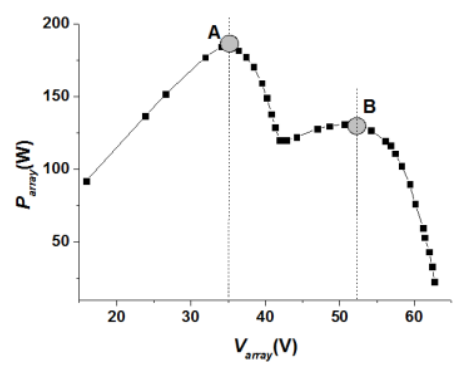

(c) Power-voltage curve

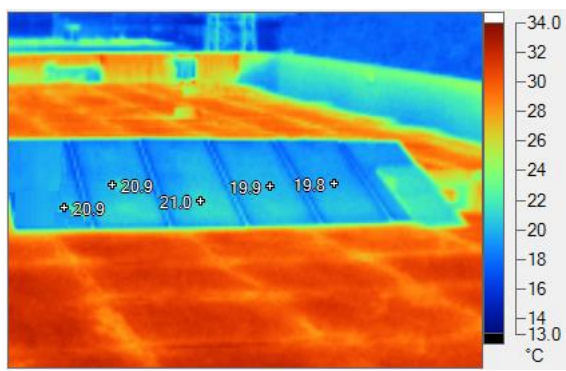

(d) Thermography at working point A

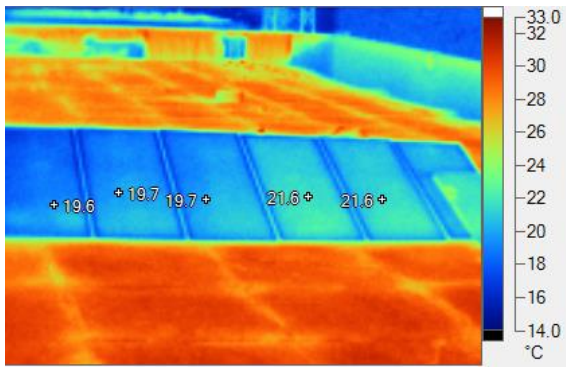

(e) Thermography at working point B

Fig. 12 Temperature distribution under two different operating points.

By the above analysis, it is clear that the temperatures of the healthy modules in both the healthy string and the unhealthy string are changed with the PV array output voltage. As a consequence, it is of critical importance to adjust the operating points according to different fault conditions. 


\section{E. Tests under Open- and Short-Circuit Faults}

Fig. 13 further compares the temperature difference between an open-circuit and a short-circuit scenario. At an open-circuit condition, the temperature distribution within a PV string is uniform; the corresponding temperature is $11.3^{\circ} \mathrm{C}$. While under a short-circuit condition, the temperature becomes varied. The temperatures of the faulty $\mathrm{PV}$ cells are $17.5^{\circ} \mathrm{C}$ and $16.6^{\circ} \mathrm{C}$; the temperature of the healthy cells is $10.8^{\circ} \mathrm{C}$, which is even lower than that at the open-circuit condition. Under a short-circuit condition, the faulty PV cells have a higher equivalent resistance, thus shifting the working point of the healthy PV cells. The fault PV cell is heated up at the same time. Therefore, the healthy cells under a short-circuit fault have a lower temperature than that at an open-circuit fault.

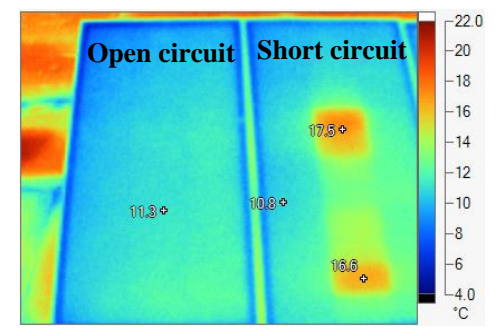

Fig. 13 Temperature difference between open- and short-circuits.

\section{F. Assistance with MPPT Control}

From the above analysis and experimental tests, the terminal characteristics and operating conditions of the PV module are known. The temperature distribution can then be input to the MPPT algorithm under mismatch fault conditions.

The maximum healthy section can be separated from fault PV arrays. As illustrated in Fig. 14, the whole PV array can be first divided into two sections: healthy and unhealthy. In the healthy section, all the modules in all strings are deemed to be fault-free. That is, there is only a maximum power point in the section (local MPP). The global MPPT is effective to locate the first local MPP, significantly reducing the search range. In the unhealthy section where one or more modules are subject to shading, the temperature distribution of the faulty PV modules is then analyzed by thermography. As a result, the global MPP operating range can be located directly without much searching effort.

\section{CONCLUSION}

Solar power is a cost-sensitive market. This work promotes its market acceptance by reducing the maintenance cost and improving the conversion efficiency of PV systems. The paper has presented a thermography-based temperature distribution analysis to analyze three different fault categories and the proposed methodology is validated by both simulation and experimental test results. The proposed technology will lower the capital and operational costs of PV plants as well as increase their energy efficiency.

Compared to the existing methods, this work has made the following improvements:

(i) The thermal camera can help locate the faulty cells instantly and guide the maintenance work to conduct according to the type of occurred faults.

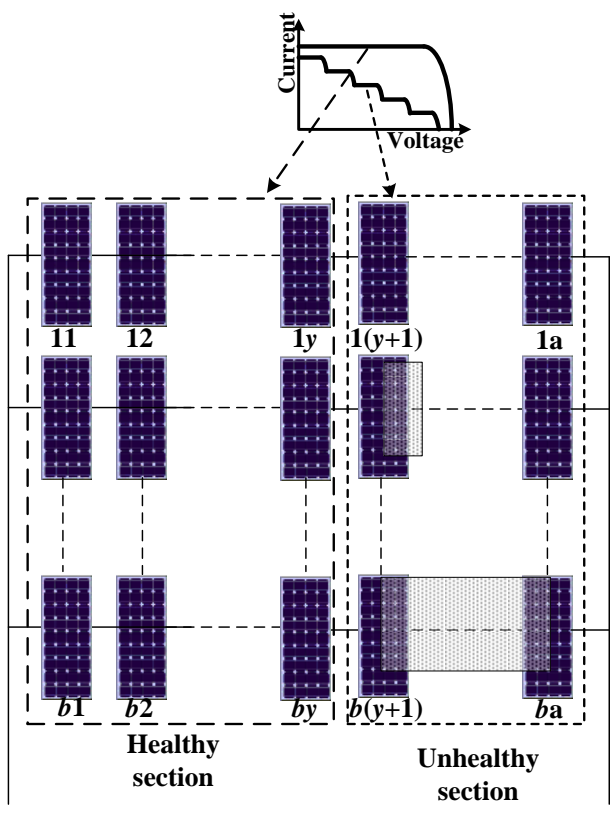

Fig. 14 Separation of healthy sections from fault PV arrays.

(ii) The temperature distributions under the PV fault conditions are analyzed by a new electrical-thermal model.

(iiI) The mechanisms and impacts of three fault categories are defined and quantitatively studied. The mechanisms and difference of three faults is also illustrated.

(iv) The operating points of healthy and faulty PV arrays are described theoretically and experimentally, which could be used to improve the PV performance upon a mismatch fault.

(v) The thermography-based temperature distribution analysis is effective to establish parameter-based models and to develop an optimized global MPPT algorithm.

\section{REFERENCES}

[1] A. Maki, S. Valkealahti, "Effect of photovoltaic generator components on the number of MPPs under partial shading conditions," IEEE Trans. Energy Conversion, Vol. 28, Issue 4, pp. 1008-1017, 2013.

[2] M.Z.S El-Dein, M. Kazerani, M.M.A. Salama, "Optimal photovoltaic array reconfiguration to reduce partial shading losses," IEEE Trans. Sustainable Energy, Vol. 4, Issue 1, pp. 145-153, 2013.

[3] E. V. Paraskevadaki, S. A. Papathanassiou, "Evaluation of MPP voltage and power of mc-Si PV modules in partial shading conditions," IEEE Trans. Energy Conversion, Vol. 26, Issue 3, pp. 923-932, 2011.

[4] H.A. Lauffenburger, R.T. Anderson, "Reliability terminology and formulae for photovoltaic power systems," IEEE Trans. Reliability, Vol. R-31, Issue 3, pp. 289-295, 1982.

[5] L.H. Stember, W.R. Huss, M.S. Bridgman, "A methodology for photovoltaic system reliability \& economic analysis," IEEE Trans. Reliability, Vol. R-31, Issue 3, pp. 296-303, 1982.

[6] T. Takashima, J. Yamaguchi, K. Otani, K. Kato, M. Ishida, "Experimental studies of failure detection methods in PV module strings," the 4th IEEE World Conference on Photovoltaic Energy Conversion, Vol. 2 pp. 2227-2230, 2006.

[7] Y.A. Mahmoud, W. Xiao, and H.H. Zeineldin, "A parameterization approach for enhancing PV model accuracy," IEEE Trans. Industrial Electronics, vol. 60, no. 12, pp. 5708-5716, 2013.

[8] Y.H. Liu, S.C. Huang, J.W. Huang, W.C. Liang, "A particle swarm optimization-based maximum power point tracking algorithm for PV systems operating under partially shaded conditions" IEEE Trans. Energy Convers., vol. 27, no. 4, pp. 1027-1035, Dec. 2012.

[9] K. Ding, X. Bian, H. Liu, T. Peng, "A MATLAB-simulink-based PV module model and its application under conditions of nonuniform irradiance," IEEE Trans. Energy Convers., vol. 27, no. 4, pp. 864-872, Dec. 2012. 
[10] A. Mäki, S. Valkealahti, "Power losses in long string and parallel-connected short strings of series-connected silicon-based photovoltaic modules due to partial shading conditions," IEEE Trans. Energy Convers., Vol. 27, no. 1, pp. 173-183, Mar. 2012.

[11] T. Takashima, J. Yamaguchi, K. Otani, T. Oozeki, K. Kato, and M. Ishida, "Experimental studies of fault location in PV module strings," Solar Energy Materials and Solar Cells, Vol. 93, no. 6-7, pp. 1079-1082, 2009.

[12] H. Patel, V. Agarwal, "Matlab-based modeling to study the effects of partial shading on PV array characteristics," IEEE Trans. Energy Conversion., Vol. 23, no. 1, pp. 302-310, 2008.

[13] H. Patel, V. Agarwal, "Maximum power point tracking scheme for PV systems operating under partially shaded conditions," IEEE Trans. Industrial Electronics, Vol. 55, Issue 4, pp. 1689-1698, 2008.

[14] H. Ziar, M. Nouri, B. Asaei, S. Farhangi, "Analysis of overcurrent occurrence in photovoltaic modules with overlapped by-pass diodes at partial shading," IEEE Journal of Photovoltaics, Vol. 4, Issue 2, pp. 713-721, Dec. 2013.

[15] A. Bidram, A. Davoudi, R. S. Balog, "Control and circuit techniques to mitigate partial shading effects in photovoltaic arrays," IEEE Journal of Photovoltaics, Vol. 2, Issue 4, pp. 532-546, 2012.

[16] E.I. Batzelis, I.A. Routsolias, S.A. Papathanassiou, "An explicit PV string model based on the lambert W function and simplified MPP expressions for operation under partial shading," IEEE Trans. Sustainable Energy, Vol. 5, Issue 1, pp. 301-312, 2014.

[17] E. Karatepe, T. Hiyama, "Simple and high-efficiency photovoltaic system under non-uniform operating conditions," IET Renewable Power Generation, Vol. 4, Issue 4, pp. 354-368, 2010.

[18] B.N. Alajmi, K.H. Ahmed, S.J. Finney, B.W. Williams, "Maximum power point tracking technique for partially shaded photovoltaic systems in microgrids," IEEE Trans. Industrial Electronics, Vol. 60, Issue 4, pp. 1596-1606, 2013.

[19] L.F. L.Villa, T.P. Ho, J.C. Crebier, B. Raison, "A power electronics equalizer application for partially shaded photovoltaic modules," IEEE Trans. Industrial Electronics, Vol. 60, Issue 3, pp. 1179-1190, 2013.

[20] G. Acciani, G.B. Simione, S. Vergura, "Thermographic analysis of photovoltaic panels," International Conference on Renewable Energies and Power Quality (ICREPQ'10), Granada, Spain, 2010.

[21] E. Kaplani, "Detection of degradation effects in field-aged c-si solar cells through IR thermography and digital image processing," International Journal of Photoenergy, Vol. 2012, Article ID: 396792, 2012.

[22] C.1. Buerhopa, D. Schlegela, M. Niessb, C. Vodermayerb, R. Weißmanna, C.J. Brabeca, "Reliability of IR-imaging of PV-plants under operating conditions," Solar Energy Materials and Solar Cells, Vol. 107, pp. 154-164, 2012.

[23] P. Parinya, B. Wiengmoon, D. Chenvidhya and C. Jivacate, "Comparative study of solar cells characteristics by temperature measurement," the 22nd European Photovoltaic Solar Energy Conference, Milan, Italy, 2007.

[24] A. Krenzinger, A.C. Andrade, "Accurate outdoor glass thermographic thermometry applied to solar energy devices," Solar Energy, Vol. 81, pp. 1025-1034, 2007.

[25] M. Simon and E.L. Meyer, "Detection and analysis of hot-spot formation in solar cells," Solar Energy Materials and Solar Cells, Vol. 94, no. 2, pp. 106-113, 2010.

[26] J. Kurnik, M. Jankovec, K. Brecl, and M. Topic, "Outdoor testing of PV module temperature and performance under different mounting and operational conditions," Solar Energy Materials \& Solar Cells, Vol. 95, pp. 373-376, 2011.

[27] G. Farivar, B. Asaei, "A new approach for solar module temperature estimation using the simple diode model," IEEE Trans. Energy Convers., Vol. 26, no. 4, pp. 1118-1126, Dec. 2011.

[28] M.U. Siddiqui, A.F.M. Arif, L. Kelley, and S. Dubowsky, "Three-dimensional thermal modeling of a photovoltaic module under varying conditions," Solar Energy, Vol. 86, no. 9, pp. 2620-2631, 2012.

[29] H.F. Tsai, H.L. Tsai, "Implementation and verification of integrated thermal and electrical models for commercial PV modules," Solar Energy, Vol. 86, Issue 1, pp. 654-665, 2012.

[30] E.L. Meyer, E. Ernest van Dyk, "Assessing the reliability and degradation of photovoltaic module performance parameters," IEEE Trans. Reliability, Vol. 53, Issue 1, pp. 83-92, 2004.

[31] A. Chatterjee, A. Keyhani, D. Kapoor, "Identification of photovoltaic source models," IEEE Trans. Energy Conversion, Vol. 26, no. 3, pp. 883-889, Sep. 2011.
[32] M. Mattei, G. Notton, C. Cristofari, M. Muselli, P. Poggi, "Calculation of the polycrystalline PV module temperature using a simple method of energy balance," Renewable Energy, Vol. 31, pp. 553-567, 2006.

[33] A. Luque, G. Sala, and J.C. Arboiro, "Electric and thermal model for non-uniformly illuminated concentration cells," Solar Energy Materials and Solar Cells, Vol. 51, pp. 269-290, 1998.

[34] Y. Hu, B. Gao, G. Y. Tian, X. Song, K. Li, X. He. "Photovoltaic fault detection using a parameter based model," Solar Energy, Vol. 96, pp. 96-10, Oct. 2013.

[35] M. Mattei, G. Notton, C. Cristofari, M. Muselli, P. Poggi, "Calculation of the polycrystalline PV module temperature using a simple method of energy balance," Renewable Energy, Vol. 31, pp.553-567, 2006.

[36] S.A. Spanoche, J.D. Stewart, S.L. Hawley, I.E. Opris, "Model-based method for partially shaded PV module hot-spot suppression," IEEE Journal of Photovoltaics, Vol. 3, Issue 2, pp. 785-790, 2013.

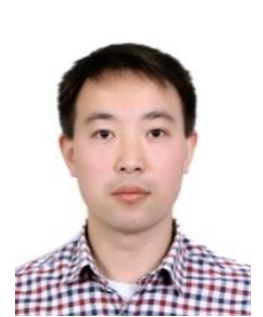

Yihua Hu (M'13) received the B.S. degree in electrical motor drives in 2003, and the Ph.D. degree in power electronics and drives in 2011, both from China University of Mining and Technology, Jiangsu, China. Between 2011 and 2013, he was with the College of Electrical Engineering, Zhejiang University, as a Postdoctoral Fellow. Between November 2012 and February 2013, he was an academic Visiting Scholar with the School of Electrical and Electronic Engineering, Newcastle University, Newcastle upon Tyne, UK. He is currently a Research Associate with the Department of Electronic \& Electrical Engineering, University of Strathclyde, Glasgow, UK. His research interests include PV generation systems, DC-DC/DC-AC converters, and electrical motor drives.

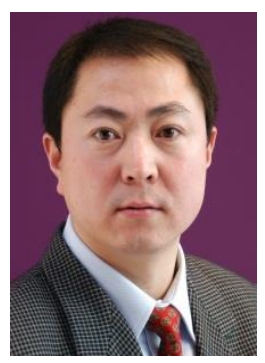

Wenping Cao (M'05-SM'11) received the B.Eng in electrical engineering from Beijing Jiaotong University, Beijing, China, in 1991; and the Ph.D. degree in electrical machines and drives from the University of Nottingham, Nottingham, U.K., in 2004. He is currently a Senior Lecturer with Queen's University Belfast, Belfast, U.K. He is the recipient of the Best Paper Award at the LDIA'13 Conference. Dr. Cao serves as an Associate Editor for IEEE Transactions on Industry Applications, IEEE Industry Applications Magazine, IET Power Electronics, and nine other International Journals. His research interests are in thermal performance of electric machines, drives and power electronics.

Dr. Cao is also a Member of the Institution of Engineering and Technology (IET) and a Fellow of Higher Education Academy (HEA).

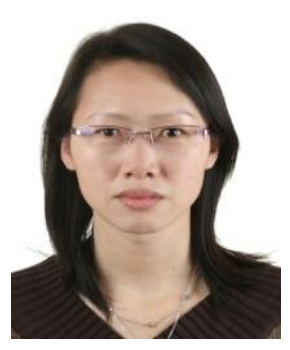

Jien Ma received the B.Eng in mechatronics from Yanshan University, Qinhuangdao, China, in 2003; and the Ph.D. in electromechanics from Zhejiang University, Hangzhou, China, in 2009. She is currently a Lecturer with the College of Electrical Engineering, Zhejiang University. Her interests are in electrical machines and drives, including PM machines and cooling system design, mechatronics machines and magneto fluid bearings.

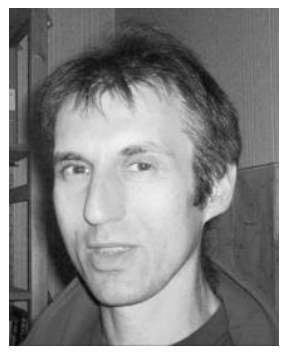

Stephen J. Finney obtained the M.Eng in electrical and electronic engineering from Loughborough University of Technology in 1988; and the Ph.D. degree from Heriot-Watt University, Edinburgh, U.K., in 1995. He worked for the Electricity Council Research Centre before joining the Power Electronics Research Group at Heriot-Watt University in 1990. From 1994 to 2005 he was a member of academic staff at Heriot-Watt University. Since 2005 he is with the Institute of Energy and Environment, University of Strathclyde 
This article has been accepted for publication in a future issue of this journal, but has not been fully edited. Content may change prior to final publication. Citation information: DOI 10.1109/TDMR.2014.2348195, IEEE Transactions on Device and Materials Reliability

where he is currently a Professor, specializing in power electronic systems. His research interests include the power electronics for high power applications and the use of power electronics for power transmission and distribution.

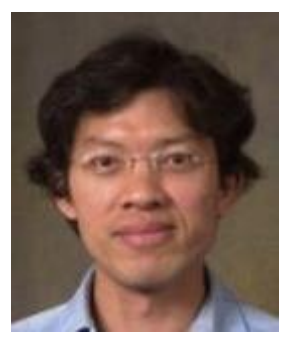

David Li received his $\mathrm{PhD}$ in electrical engineering from National Taiwan University in 2001. He then joined the Industrial Technology Research Institute (ITRI), Taiwan, and University of Edinburgh, working on optical communications and optoelectronics. From Jan 2014, he is with the Centre for Biophotonics, University of Strathclyde, as a Senior Lecturer. His current research interests include solid-state cameras, embedded systems, digital signal processing, mixed-signal integrated circuits design, fluorescence based sensing and imaging systems, electrical impedance sensing systems, forward models of electrical impedance tomography, finite-element/finite-difference and numerical modelling. 